\title{
Mitigasi Bencana untuk Daerah Rawan Longsor
}

\section{Disaster Mitigation for Landslide Prone Areas}

\author{
Dhi Bramasta ${ }^{1}$, Sriyanto ${ }^{2}$ \\ 1,2Primary School Teacher Education Study Program \\ Teacher Training and Education Faculty, Universitas Muhammadiyah Purwokerto
}

\begin{tabular}{l}
\hline \hline ARTICLE INFO \\
\hline Article history: \\
DOI: \\
10.30595/pssh.v1i.78 \\
Submitted: \\
April 12, 2021 \\
Accepted: \\
June 10, 2021 \\
Published: \\
June 14, 2021 \\
\hline
\end{tabular}

\section{Keywords:}

Landslides, Disaster Mitigation

\begin{abstract}
Natural disasters are natural occurrences that have an impact on the environment, which can be in the form of damage, causing casualties, loss of property, damage to infrastructure and life facilities and infrastructure. Avalancheor often called ground movement is an event geology that happens because of the movement of the masses rock or soil with various types and types such as falling rocks or large lumps of soil. In general, there are two factors that can cause landslides, namely driving factors and triggering factors. Driving factors are factors that influence the condition of the material itself, while trigger factors are factors that cause the movement of the material. However, the main cause is gravity which affects a steep slope, but there are other factors that trigger it. Indonesia is located on the three main plates of the world, namely the Pacific, Australian and Eurasian plates which cause Indonesia to experience frequent disasters. In addition, Indonesia is geomorphologically a country that has a complete land form. Starting from mountains, slopes, savanna, marine or coastal areas. Diverse topography and land use change will be one of the causes of landslides. Various topographical conditions and the many different land functions that occur in Indonesia are one of the factors causing landslides, so knowledge of landslide disaster mitigation in landslide-prone areas is absolutely necessary to realize disaster preparedness, namely to reduce losses and casualties due to disasters. This can be done in three stages, namely before a landslide disaster occurs, during a landslide disaster and after a landslide disaster occurs. Hence, knowledge of landslide disaster mitigation in landslide-prone areas is absolutely necessary to realize disaster preparedness, namely to reduce losses and casualties due to disasters. This can be done in three stages, namely before a landslide disaster occurs, during a landslide disaster and after a landslide disaster occurs. Hence, knowledge of landslide disaster mitigation in landslide-prone areas is absolutely necessary to realize disaster preparedness, namely to reduce losses and casualties due to disasters. This can be done in three stages, namely before a landslide disaster occurs, during a landslide disaster and after a landslide disaster occurs.
\end{abstract}

This work is licensed under a Creative Commons Attribution 4.0 International License.

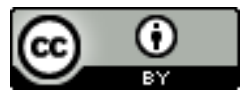

\section{Corresponding Author:}

Dhi Bramasta, Sriyanto

Primary School Teacher Education Study Program

Teacher Training and Education Faculty, Universitas Muhammadiyah Purwokerto

Jl. KH. Ahmad Dahlan, Dusun III, Dukuhwaluh, Kec. Kembaran, Kabupaten Banyumas, Jawa Tengah, Indonesia. Email: dhibramasta0891@gmail.com, sriyanto1907@gmail.com

\section{PENDAHULUAN}

Bencana alam atau natural disaster, merupakan suatu peristiwa alam yang mengakibatkan dampak besar bagi populasi manusia. Peristiwa alam dapat berupa banjir, letusan gunung berapi, gempa bumi, tsunami, tanah longsor, badai salju, kekeringan, hujan es, gelombang panas, hurikan, badai tropis, topan, tornado, kebakaran liar 
dan wabah penyakit. Dalam Undang-undang Nomor 24 Tahun 2007 tentang penanggulangan bencana menjelaskan bahwa bencana adalah peristiwa atau rangkaian peristiwa yang mengancam dan mengganggu kehidupan dan penghidupan masyarakat yang disebabkan, baik oleh faktor alam dan atau faktor non alam maupun faktor manusia sehingga mengakibatkan timbulnya korban jiwa manusia, kerusakan lingkungan, kerugian harta benda, dan dampak psikologis [1]. Lebih lanjut manurut Parker (1992) menjelaskan bahwa bencana adalah sebuah kejadian yang tidak biasa terjadi disebabkan oleh alam maupun ulah manusia, termasuk pula di dalamnya merupakan imbas dari kesalahan teknologi yang memicu respon dari masyarakat, komunitas, individu maupun lingkungan untuk memberikan antusiasme yang bersifat luas [2]. Hal serupa juga disampaikan oleh Asian Disaster Reduction Center (2003) yang menyatakan bahwa bencana adalah gangguan serius terhadap masyarakat yang menimbulkan kerugian secara meluas dan dirasakan baik oleh masyarakat, berbagai material dan lingkungan (alam) dimana dampak yang ditimbulkan melebihi kemampuan manusia guna mengatasinya dengan sumberdaya yang ada [3].

Indonesia merupakan negara kepulauan yang berada diantara dua benua dan dua samudera yaitu Benua Asia dan Benua Australia, Samudera Hindia dan Samudera Pasifik. Secara geologis Indonesia terletak di antara dua sirkum yaitu Sirkum Mediterania dan Sirkum Pasifik. Disamping itu juga terletak pada tiga lempeng utama dunia, yaitu lempeng Pasifik, Australian dan Eurasia. Letak geologis merupakan letak suatu wilayah yang dilihat dari faktor kondisi batuan di permukaan bumi. Dengan posisi ini, Indonesia sering sekali dilanda bencana, termasuk tanah longsor. Dilihat dari segi geologi Indonesia berada pada jalur ring of fire. Yaitu merupakan jalur gunung berapi yang membentang mengelilingi cekungan pasifik. Jalur ini di tandai dengan deretan gunung berapi yang ada di Pulau Sumatera hingga Pulau Jawa dan Sulawesi. Secara geomorfologi, permukaan bumi Indonesia memiliki bentuk lahan yang lengkap. Mulai dari gunung, lereng, sabana, marine atau wilayah pantai. Topografi yang beragam dan alih fungsi lahan akan menjadi salah satu penyebab dari bencana tanah longsor. Sedangkan tanah longsor sendiri adalah perpindahan masa tanah atau batuan dengan arah miring dari kedudukan semula akibat gaya gravitasi Sutikno dkk (2002) [4].

Mengingat Indonesia memiliki bentuk lahan yang sangat beragam tersebut maka tanah longsor sering terjadi di Indonesia. Berikut beberapa penyebab terjadinya tanah longsor yaitu tingkat pelapukan, tingkat curah hujan, kemiringan lereng, struktur geologi, intensitas gempa bumi.

Suatu daerah yang memiliki kemiringan lereng yang terjal seperti daerah gunung/pegunungan, memiliki intensitas hujan yang tinggi seperti daerah dengan dataran tinggi, tingkat pelapukan tinggi biasanya terjadi pada daerah gurun, karena memiliki iklim yang kontinental yaitu pada siang hari suhu sangat panas menyebabkan batuan mengembang dan pada saat malam suhunya sangat dingin yang menyebabkan batuan mengerut sehingga menyebabkan batuan di daerah gurun mudah lapuk (retak, pecah). Daerah-daerah tersebut sangat rawan sekali terjadi tanah longsor.

Bencana tanah longsor akan selalu membawa dampak terhadap daerah yang mengalami tanah longsor, demi mengurangi resiko bencana yang ditimbulkan akibat bencana, maka kesiapsiagaan perlu untuk ditanamkan pada masyarakat. Hal tersebut dapat dilakukan melalui mitigasi bencana tanah longsor. (Depdagri, 2003) menyampaikan bahwa mitigasi (penjinakan) adalah segala upaya dan kegiatan yang dilakukan untuk mengurangi dan memperkecil akibat-akibat yang ditimbulkan oleh bencana, yang meliputi kesiapsiagaan serta penyiapan kesiapan fisik, kewaspadaan dan kemampuan mobilisasi [5]. Sedangkan pada Pasal 1 ayat 6 PP No 21 Tahun 2008 tentang penyelenggaraan penanggulangan bencana. Mitigasi bencana adalah serangkaian upaya untuk mengurangi risiko bencana, baik melalui pembangunan fisik maupun penyadaran dan peningkatan kemampuan menghadapi ancaman bencana [6].

Salah satu daerah rawan longsor yang berada di Kabupaten Banyumas mengalami bencana tanah longsor pada bulan Oktober 2020 melalui Media Indonesia, Badan Penanggulangan Bencana Daerah (BPBD) Banyumas menjelaskan bahwa telah terjadi tanah longsor di salah satu wilayah di Banyumas yang diakibatkan oleh hujan yang deras. Lebih lanjut BPBD menghimbau kepada masyarakat untuk meningkatkan kewaspadaan. Karena, memasuki musim pancaroba maka ada potensi hujan deras. Karena itu, wilayah-wilayah yang rawan longsor harus waspada. Masa pancaroba adalah peralihan dari musim kemarau ke musim penghujan. Pada masa transisi ini, curah hujan memiliki intensitas ringan hingga sedang. Diperkirakan pada bulan September hingga awal Oktober merupakan musim pancaroba yang ditandai dengan hujan tidak merata, yang hal tersebut dapat mengakibatkan terjadinya tanah longsor (https://mediaindonesia.com/read/detail/346851-bencana-tanah-longsor ancam-beberapa-wilayah-dibanyumas) [7].

Guna mengurangi resiko bencana yaitu dengan mengetahui langkah yang harus dilakukan bagi daerah rawan bencana melalui mitigasi bencana. Baik dalam meningkatkan kesiapsiagaan, mengetahui langkah yang harus dilakukan sebelum, saat dan paska terjadi bencana. Harapannya dapat mengurangi resiko bencana yang ditimbulkan kaibat bencana.

\section{METODE PENELITIAN}

Observasi digunanakan dalam rangka mengetahui kondisi daerah yang rentan terhadap tanah longsor dan wawancara untuk mengetahui apakah langkah-langkah ataupun tindakan yang harus dilakukan ketika menghadapi 
bencana tanah longsor sudah diketahui atau dipahami oleh masyarakat. Studi literatur dan simulasi dilaksanakan dalam rangka memberikan gambaran dan pemahaman bagaimana melaksanakan tahapan langkah-langkah dalam menghadapi bencana tanah longsor bagi daerah rawan longsor.

\section{HASIL DAN PEMBAHASAN}

\section{A. Bencana}

Bencana adalah peristiwa atau rangkaian peristiwa yang mengancam dan mengganggu kehidupan dan penghidupan masyarakat yang disebabkan, baik oleh faktor alam dan/atau faktor non alam maupun faktor manusia sehingga mengakibatkan timbulnya korban jiwa manusia, kerusakan lingkungan, kerugian harta benda, dan dampak psikologis.

Bencana berdasarkan sumbernya dibagi menjadi tiga, yaitu:

1. Bencana alam, adalah bencana yang diakibatkan oleh peristiwa/serangkaian peristiwa oleh alam.

2. Bencana nonalam, adalah bencana yang diakibatkan oleh peristiwa/serangkaian peristiwa nonalam

3. Bencana sosial, adalah bencana yang diakibatkan oleh peristiwa/serangkaian peristiwa oleh manusia

Bencana alam juga dapat dikelompokkan sebagai berikut:

1. Bencana alam meteorologi (hidrometeorologi). Berhubungan dengan iklim. Umumnya tidak terjadi pada suatu tempat yang khusus.

2. Bencana alam geologi. Adalah bencana alam yang terjadi di permukaan bumi seperti gempa bumi, tsunami, dan longsor.

Penyebab bencana alam di Indonesia:

1. Posisi geografis Indonesia berada diantara dua samudera besar.

2. Posisi geologis Indonesia pada pertemuan tiga lempeng utama dunia (Indo-Australia, Eurasia, Pasifik).

3. Kondisi permukaan wilayah Indonesia (relief) yang sangat beragam.

\section{B. Mitigasi Bencana}

Mitigasi bencana adalah serangkaian upaya untuk mengurangi risiko bencana, baik melalui pembangunan fisik maupun penyadaran dan peningkatan kemampuan menghadapi ancaman bencana (Pasal 1 ayat 6 PP No 21 Tahun 2008 Tentang Penyelenggaraan Penanggulangan Bencana) [6].

Tujuan mitigasi bencana yaitu :

1. Mengurangi dampak yang ditimbulkan, khususnya bagi penduduk.

2. Sebagai landasan (pedoman) untuk perencanaan pembangunan.

3. Meningkatkan pengetahuan masyarakat dalam menghadapi serta mengurangi dampak/resiko bencana, sehingga masyarakat dapat hidup dan bekerja dengan aman.

Beberapa kegiatan mitigasi bencana di antaranya:

1. Pengenalan dan pemantauan risiko bencana;

2. Perencanaan partisipatif penanggulangan bencana;

3. Pengembangan budaya sadar bencana;

4. Penerapan upaya fisik, nonfisik, dan pengaturan penanggulangan bencana;

5. Identifikasi dan pengenalan terhadap sumber bahaya atau ancaman bencana;

6. Pemantauan terhadap pengelolaan sumber daya alam;

7. Pemantauan terhadap penggunaan teknologi tinggi;

8. Pengawasan terhadap pelaksanaan tata ruang dan pengelolaan lingkungan hidup.

\section{Mitigasi Bencana Tanah Longsor}

Sutikno dkk (2002) berpendapat bahwa Tanah longsor adalah perpindahan masa tanah atau batuan dengan arah miring dari kedudukan semula akibat gaya gravitasi [4]. Sedangkan Sitorus (2006), menyampaikan bahwa longsoran dapat diartikan sebagai suatu bentuk erosi yang pengangkutannya atau perpindahan tanahnya terjadi pada suatu saat yang relatif pendek dalam volume (jumlah) yang sangat besar [8]. Sehingga dapat diambil kesimpulan bahwa longsoran tanah atau lahan adalah merupakan bagian dari aktivitas tanah yang jatuh menuruni lereng dapat berupa material tanah, bebatuan dan material lain akibat gaya gravitasi serta daya dukung tanah berkurang.

Penyebab terjadinya tanah longsor antara lain adalah:

1. Lereng

Menurut Karnawati (2005), kelerengan menjadi faktor yang sangat penting dalam proses terjadinya tanah longsor. Pembagian zona kerentanan sangat terkait dengan kondisi kemiringan lereng. Kondisi kemiringan lereng yang terjal perlu mendapat perhatian terhadap kemungkinan bencana longsor dan tentunya dengan mempertimbangkan faktor-faktor lain yang mendukung. Pada dasarnya sebagian besar wilayah di Indonesia merupakan daerah perbukitan atau pegunungan 
yang membentuk lahan miring. Namun tidak selalu lereng atau lahan yang miring berbakat atau berpotensi longsor. Potensi terjadinya gerakan pada lereng juga tergantung pada kondisi batuan dan tanah penyusun lerengnya, struktur geologi, curah hujan, vegetasi penutup, dan penggunaan lahan pada lereng tersebut [9].

2. Penutup Vegetasi atau Penggunaan Lahan

Tanaman mampu menahan air hujan agar tidak merembes untuk sementara, sehingga bila dikombinasikan dengan saluran drainase dapat mencegah penjenuhan material lereng dan erosi. Keberadaan vegetasi pada kondisi lereng yang terjal atau curam juga mencegah longsor dan pelapukan lebih lanjut. Pola tanam yang tidak tepat justru berpotensi meningkatkan bahaya longsorlahan. Jenis tanaman apa pun yang ditanam saat rehabilitasi harus sesuai dengan kondisi geofisik dan sejalan dengan tujuan akhir rehabilitasi lahan. Pohon yang cocok ditanam di lereng terjal atau curam adalah yang tidak terlalu tinggi, namun memiliki jangkauan akar yang luas sebagai pengikat tanah (Surono, 2003) [10].

3. Jenis Tanah

Jenis tanah sangat menentukan terhadap potensi longsorlahan. Tanah yang gembur karena mudahnya air masuk ke dalam penampang tanah akan lebih berpotensi longsor dibandingkan dengan tanah yang padat (massive) seperti tanah bertekstur liat (clay). Setiap jenis tanah memiliki kepekaan terhadap longsor yang berbeda-beda. Kepekaan longsorlahan yaitu mudah atau tidaknya longsorlahan merupakan fugsi berbagai interaksi sifat-sifat fisik tanah. Sifat-sifat tanah yang mempengaruhi kepekaan longsor, adalah tekstur, struktur, bahan organik, solum tanah, sifat lapisan tanah, dan tingkat kesuburan tanah. Hasil penelitian Arsyad (1989) menunjukkkan tanah regosol dari bahan volkan dan regosol merupakan tanah yang sangat peka longsor, bila dibandingkan dengan tanah andosol atau latosol yang merupakan tanah yang terbentuk dari bahan volkan. Jenis tanah yang kurang padat adalah tanah lempung atau tanah liat dengan ketebalan lebih dari $2,5 \mathrm{~m}$ dan sudut lereng dari $220 \%$. Tanah jenis ini memiliki potensi untuk terjadinya longsorlahan terutama bila terjadi hujan. Selain itu tanah ini sangat rentan terhadap pergerakan tanah karena menjadi lembek terkena air dan pecah ketika suhu terlalu panas [11].

4. Curah Hujan

Karnawati (2005) menyatakan salah satu faktor penyebab terjadinya bencana longsorlahan adalah air hujan [9]. Air hujan yang telah meresap ke dalam tanah lempung pada lereng akan tertahan oleh batuan yang lebih kompak dan lebih kedap air. Derasnya hujan mengakibatkan air yang tertahan semakin meningkatkan debit dan volumenya dan akibatnya air dalam lereng ini semakin menekan butiran-butiran tanah dan mendorong tanah lempung pasiran untuk bergerak. Batuan yang kompak dan kedap air berperan sebagai penahan air dan sekaligus sebagai bidang gelincir longsoran, sedangkan air berperan sebagai penggerak massa tanah yang tergelincir di atas batuan kompak tersebut. Semakin curam kemiringan lereng maka kecepatan penggelinciran juga semakin cepat. Semakin gembur tumpukan tanah lempung maka semakin mudah tanah tersebut meloloskan air dan semakin cepat air meresap ke dalam tanah. Semakin tebal tumpukan tanah, maka juga semakin besar volume massa tanah yang longsor. Tanah yang longsor dengan cara demikian umumnya dapat berubah menjadi aliran lumpur yang pada saat longsor sering menimbulkan suara gemuruh. Hujan dapat memicu longsor melalui penambahan beban lereng dan menurunkan kuat geser tanah. Menurut Suryolelono (2005), pengaruh hujan dapat terjadi di bagian-bagian lereng yang terbuka akibat aktivitas mahluk hidup terutama berkaitan dengan budaya masyarakat saat ini dalam memanfaatkan alam berkaitan dengan pemanfaatan lahan (tata guna lahan), kurang memperhatikan pola-pola yang sudah ditetapkan oleh pemerintah [12].

Penebangan hutan yang seharusnya tidak diperbolehkan tetap saja dilakukan, sehingga lahan-lahan pada kondisi lereng dengan geomorfologi yang sangat miring, menjadi terbuka dan lereng menjadi rawan longsor. Air permukaan yang membuat tanah menjadi basah dan jenuh akan sangat rawan terhadap longsor. Hujan yang tidak terlalu lebat, tetapi berjalan berkepanjangan lebih dari satu atau dua hari, akan berpeluang untuk menimbulkan longsor lahan.

5. Gempa Bumi atau Gerakan Tanah

Gempa menimbulkan getaran yang menyebabkan longsor lahan. Daerah yang sering terjadi gempa dan memiliki kondisi lereng yang curam atau terjal maka lebih rawan terhadap longsorlahan dibandingkan daerah yang tidak rawan gempa.

Terdapat ciri yang dapat dijadikan sebagai hal untuk mengetahui akan terjadinya tanah longsor, yaitu:

a. Setelah terjadi hujan, tampak ada retakan pada lereng,

b. Kerikil berjatuhan, tebing terlihat kurang kokoh atau rapuh,

c. Tiba-tiba timbul mata air baru, 
d. Genangan air saat musim hujan akan lenyap saat akan terjadi longsor,

e. Pintu maupun jendela sukar terbuka,

f. Pepohonan tampak miring,

g. Halaman rumah atau dalam rumah mendadak ambles.

Dampak bencana tanah longsor antara lain:

a. Dampak Positif

1) Mampu meningkatkan kesadaran masyarakat pentingnya menjaga alam ketika terjadi tanah longsor.

2) Meningkatkan kepedulian antar masyarakat, karena ada banyak orang yang menolong korban-korban tanah longsor.

3) Dapat meningkatkan kewaspadaan bagi masyarakat yang tinggal disekitar wilayah rawan tanah longsor.

4) Ketika terjadi tanah longsor, wilayah yang mengalami tanah longsor dapat dijadikan tempat penelitian oleh ahli-ahli geologi.

b. Dampak Negatif

1) Dapat mengancam keselamatan dan korban jiwa apabila terjadi disekitar pemukiman masyarakat.

2) Dapat menghancurkan infrastruktur dan kerugian material.

3) Perekonomian daerah yang mengalami bencana tanah longsor mengalami kerugian karena akses jalan yang material tanah yang longsor.

\section{Langkah-langkah Mitigasi Bencana Tanah Longsor}

\section{1) Sebelum Bencana Tanah Longsor}

a) Mengurangi tingkat keterjalan lereng permukaan maupun air tanah. Perhatikan fungsi drainase adalah untuk menjauhkan air dari lereng, menghindari air meresap ke dalam lereng atau menguras air ke dalam lereng ke luar lereng. Jadi drainase harus dijaga agar jangan sampai tersumbat atau meresapkan air ke dalam tanah.

b) Membuat bangunan penahan, jangkar (anchor) dan pilling.

c) Menghindari membangun rumah, fasilitas umum atau pemukiman di daerah yang rawan terjadi bencana.

d) Membuat terasering dengan sistem drainase yang tepat (drainase pada teras-teras dijaga jangan sampai menjadi jalan meresapkan air ke dalam tanah).

e) Melakukan penghijauan dengan tanaman yang sistem perakarannya dalam menembus tanah dan jarak tanam yang tepat (khusus untuk lereng curam, dengan kemiringan lebih dari 40 derajat atau sekitar $80 \%$ sebaiknya tanaman tidak terlalu rapat serta diseling-selingi dengan tanaman yang lebih pendek dan ringan, di bagian dasar ditanam rumput).

f) Apabila hendak mendirikan bangunan, upayakan memiliki fondasi yang kuat.

g) Melakukan pemadatan tanah di sekitar perumahan terutama yang paling dekat dengan daerah rawan longsor. Selain itu lakukan sosialisasi atau pengenalan daerah yang rawan longsor.

h) Membangun tanggul penahan untuk runtuhan batuan (rock fall).

i) Penutupan rekahan di atas lereng untuk mencegah air masuk secara cepat ke dalam tanah.

j) Pondasi tiang pancang sangat disarankan untuk menghindari bahaya liquefaction (infeksi cairan).

k) Utilitas yang ada di dalam tanah harus bersifat fleksibel.

1) Dalam beberapa kasus relokasi sangat disarankan. Menanami kawasan yang gersang dengan tanaman yang memiliki akar kuat, banyak dan dalam seperti nangka, durian, pete, kaliandra dan sebagainya.

Selain itu perhatikan juga beberapa aspek berikut:

a) Tidak mendirikan bangunan permanen di daerah tebing dan tanah yang tidak stabil (tanah gerak).

b) Membuat selokan yang bisa mengalirkan air hujan sehingga air tidak meresap ke tanah yang berkemungkinan longsor.

c) Selalu waspada dan bersiap dan sedia ketika curah hujan tinggi.

d) Jangan membiarkan hutan gundul atau pun melakukan penebangan sehingga membuat tanah tak punya penopang.

2) Langkah Saat Terjadi Bencana Tanah Longsor

a) Apabila mendengar suara gemuruh terutama apabila rumah dekat lereng mauapun tanah yang rawan longsor, segera evakuasi untuk menjauhi suara gemuruh atau arah datangnya longsoran.

b) Apabila mendengar suara sirine peringatan longsor, segera evakuasi ke arah zona evakuasi yang telah ditentukan. (Beberapa wilayah di Indonesia telah terpasang Sistem Peringatan Dini Longsor).

3) Langkah Setelah Terjadi Bencana Tanah Longsor

Setelah bencana selesai, dapat melakukan langkah-langkah berikut: 
a) Walaupun longsor sudah terjadi, belum tentu ada pohon maupun material lain yang akan menyusul jatuh, sehingga hindari wilayah longsor karena kondisi tanah yang labil.

b) Apabila hujan turun setelah longsor terjadi, antisipasi longsor susulan.

\section{KESIMPULAN}

Bencana alam merupakan kejadian alam yang memberikan dampak terhadap lingkungan, dapat berupa kerusakan, menimbulkan adanya korban jiwa, kerugian harta benda, rusaknya infrastruktur dan sarana dan prasarana kehidupan. Longsor atau sering disebut gerakan tanah adalah suatu peristiwa geologi yang terjadi karena pergerakan masa batuan atau tanah dengan berbagai tipe dan jenis seperti jatuhnya bebatuan atau gumpalan besar tanah. Indonesia memiliki bentuk lahan yang lengkap. Mulai dari gunung, lereng, sabana, marine atau wilayah pantai. topografi yang beragam dan alih fungsi lahan akan menjadi salah satu penyebab dari bencana tanah longsor.

Bencana tanah longsor akan selalu membawa dampak terhadap daerah yang mengalami tanah longsor, demi mengurangi resiko bencana yang ditimbulkan akibat bencana, maka kesiapsiagaan perlu untuk ditanamkan pada masyarakat. Dalam rangka meningkatkan kesiapsiagaan dan mengurangi resiko bencana dapat dilakukan dengan mitigasi bencana dari tahapan sebelum terjadi bencana tanah longsor, saat terjadi bencana tanah longsor dan setelah terjadi bencana tanah longsor.

\section{DAFTAR PUSTAKA}

[1] Undang-undang RI. No. 24 tahun 2007. Penanggulangan Bencana. Jakarta.

[2] Parker. (1992). Pencegahan dan Manajemen Bencana. http://socialstudies17.blogspot.com/2012/11/recognize-pencegahan-bencana-dan.html. Diakses tanggal 14 September 2020.

[3] Asian Disaster Reduction. (2003). Definisi Bencana. Asian Disaster Reduction.

[4] Sutikno, Huda, M., Sarwondo, Triyono. (2002). Sistem Penanggulangan Bencana Alam Tanah Longsor Kabupaten Kulonprogo, dalam Permasalahan dan Pengelolaan Bencana Sedimen di Indonesia, Prosiding, Yogyakarta.

[5] DEPDAGRI, (2003). Keputusan Menteri Dalam Negeri No. 131 Tahun 2003. Tentang Pedoman Penanggulangan Bencana dan Penanganan Pengungsi di Daerah. Jakarta: Direktorat Perlindungan Masyarakat, Direktorat Jenderal Kesatuan Bangsa.

[6] Peraturan Pemerintah No. 21 tahun 2008 Tentang Penyelenggaraan Penanggulangan Bencana.

[7] E-paper Media Indonesia.com. Penerbit Media Indonesia. Bencana Tanah Longsor Ancam Beberapa Wilayah di Banyumas. 22 September 2020. 14.10 (Diakses 21 Oktober 2020). https://mediaindonesia.com/read/detail/346851-bencana-tanah-longsor\%20ancam-beberapa-wilayah-dibanyumas.

[8] Sitorus, S. (2006). Pengembangan Lahan Berpenutupan Tetap sebagai Kontrol Terhadap Faktor Resiko dan Bencana Longsor. Jakarta: Direktorat Jendral Penataan Ruang Departmen Pekerjaan Umum.

[9] Karnawati, D. (2005). Bencana Alam Gerakan Massa Tanah di Indonesia dan Upayah Penangulangannya. Jurusan Teknik Geologi Fakultas Teknik Universitas Gaja Mada. Yogyakarta.

[10] Surono. (2003). Potensi Bencana Geologi di Kabupaten Garut. Pemerintah Kabupaten Garut.

[11] Arsyad, S. (1989). Konservasi Tanah dan Air. Bogor: Institut Pertanian Bogor Press.

[12] Suryolelono, K.B. (2005). Bencana Alam Tanah Longsor Perspektif Ilmu Geoteknik. 